\title{
Reconstruction of a Green Open Space (RTH) Policy in Indonesia Based on the Value of Justice
}

\author{
Agus Widodo $^{1 *}$, Gunarto ${ }^{2}$, Edy Lisdiyono ${ }^{3}$ \\ ${ }^{1}$ Doctorate Student of Faculty of Law Sultan Agung Islamic University Semarang, Indonesia \\ ${ }^{2}$ Faculty of Law Sultan Agung Islamic University Semarang, Indonesia \\ ${ }^{3}$ Faculty of Law 17 Agustus 1945 University Semarang, Indonesia
}

DOI: $\underline{10.36348 / \text { sijlcj.2021.v04i03.005 }}$

| Received: 21.02.2021 | Accepted: 15.03.2021 | Published: 16.03.2021

*Corresponding author: Agus Widodo

\section{Abstract}

Green open space is needed for big cities in Indonesia like Semarang City, for example. However, along with the proliferation of development due to increasing population, green open spaces are increasingly being eroded. According to the author, this is interesting to be examined in a study with the subject matter of what are the obstacles that arise in the enforcement of green open space in Indonesia Currently and how to reconstruct these rules to better reflect the value of justice. In examining the main problem, the author uses the empirical juridical research method with primary data obtained from the field which, in this case, obtained from Semarang City as a Sample supported by secondary data from the literature and the law that is studied using data triangulation. The results showed that the obstacles in the establishment of Green Open Space in Indonesia as seen in Semarang City are the aspects of law enforcement approaches that are still formalistic and conventional. Therefore, it is necessary to have a Reconstruction of Green Open Space utilization policy in Law Number 26 of 2007 concerning Spatial Planning, Article 1 number 31 concerning the meaning of Green Open Space by referring to the provisions of RTH Singapore so that economic interests and environmental preservation can go hand in hand.

Keywords: Reconstruction, Green Open Space, Justice Value.

Copyright ( $) 2021$ The Author(s): This is an open-access article distributed under the terms of the Creative Commons Attribution 4.0 International License (CC BY-NC 4.0) which permits unrestricted use, distribution, and reproduction in any medium for non-commercial use provided the original author and source are credited.

\section{INTRODUCTION}

Regional Spatial Planning (RTRW) is a policy direction and strategy for the utilization of state territory which is used as a reference for long-term planning. The term of the Regional Spatial Plan is 20 (twenty) years, reviewed 1 (one) time in 5 (five) years.

The existence of this RTRW requires integral and balanced planning for each province and district/city throughout Indonesia. Green open space arrangement is an important step to achieve the goals of urban planning activities, as well as cities in Indonesia, such as; Surabaya, Bandung, Makassar, Medan, and Semarang, which are international trade and service centers that are safe, comfortable, productive, directed towards the development of sustainable spatial and regional planning. According to Kodoatie and Sjarief [1], spatial planning means the activities of regulation, development, implementation, supervision of spatial planning and others carried out by government officials as an effort to implement all forms of policies that have been determined in accordance with the provisions of the applicable laws.

The principle that needs to be put forward for every regional leader is to build a region that is in line with the principle of sustainable regional autonomy. The regional head should carefully calculate the capacity of the natural resources of the region, about the fate of future generations, as well as how to improve the quality of life for the nation's children and neighbors and in order to realize this goal, policies, and programs that support environmental conservation need to be made and in this case, are realized by the government with the Law Number 26 of 2007 concerning Spatial Planning which contains provisions on the provision of Green Open Space (RTH).

Semarang City as one of the big cities in Indonesia, following this law has made Regional Regulation Number 14 of 2011 concerning Semarang City Spatial Planning 2011-2031 which at the time of its enactment was the first regional regulation on spatial 
Agus Widodo et al., Sch Int J Law Crime Justice, Mar, 2021; 4(3): 159-165

planning passed for the category of metropolitan cities throughout Indonesia. This achievement must be followed by the implementation of a good spatial plan in terms of utilization and control.

Semarang City Spatial Planning 2011-2031 is divided into 3 (three) spatial planning policies, as stated in Semarang City Regional Regulation Number 14 of 2011 concerning RTRW 2011-2031:

1. Spatial structure development policies and strategies;

2. Spatial pattern development policies and strategies;

3. Strategic area development policies and strategies.

Of the three policies related to the conditions to be studied are policies and strategies for developing spatial patterns. The spatial pattern means the distribution of spatial use in an area which includes the space allocation for the protection function and the spatial allocation for the cultivation function. Spatial pattern development policies and strategies include policies and strategies for managing protected areas and policies and strategies for developing cultivation areas in which there are regulations to maintain the function and organize existing green open spaces as stated in Article 6 paragraph 4 .

Green open space means an elongated area or pathway or group whose use is more open, a place for plants to grow, both those that grow naturally or are intentionally planted and the said area must be free of buildings.

However, the current conditions in society as can be seen in the city of Semarang where the population growth of Semarang City during the last 5 (five) years of 1.10 percent indicates that more and more residents of Semarang city need new housing areas that must be provided by Semarang City Government [2]. Therefore, it greatly affects the need for development which is expected to expand the existence of these buildings.

The ever-increasing population of Semarang has influenced housing developers to build housing areas in outer sub-districts, including Mijen, Tembalang, and Gunungpati Districts, with the consideration that these three areas are strategic areas for housing construction seeing that all three areas are still beautiful and green so that the concept of housing can be built together with nature.

In fact, it can be seen that the type of area that continues to deplete is actually a catchment area. This infiltration area is a form of green open space that must be maintained. The Mijen sub-district has a rubber-tree forest in the Bukit Semarang Baru housing area that carries out various functions from maintaining groundwater order to regulating the climate and overcoming air pollution. Likewise, the Tembalang District area still has a lot of vegetation in the form of forests, so that it can functions as the lungs of the city, the benefits of the infiltration area are clearly felt by the surrounding environment.

Currently, the paradigm of forest management is for intensive use in order to encourage urban economic growth, the area that was originally a rubber production forest has turned into a residential area. The city government allocates a large number of concessions to private companies. In areas that have been converted into "planned deforestation", it is permissible to open and free forest areas for other uses. The conversion of the rubber forest function in the Bukit Semarang Baru (BSB) area, which is planned to be turned into a satellite city, has had a bad environmental impact. Floods in the Mangkang area and its surroundings often occur, due to reduced water catchment areas, so that the flow of rainwater that is not absorbed by the soil falls to lower areas. The BSB area, which has an area of more than 30 hectares, is considered quite unsettling, the plan is to become a new city center with land from the acquisition of part of the Semarang city forest gradually, so it can be ascertained that the impact felt by the surrounding area is flooding because the BSB area enlarges the run off in the area. This has an impact on the amount of rain water flowing into the Mangkang area to increase and making the area flooded because there is no conservation area.

The problems as mentioned above are what urge the author to study the problems further as it is necessary in order to build a better law wherein this study is concentrated on 2 main problems as follows:

1. What Are The Obstacles That Arise In Indonesia's Green-Space Arrangement (RTH) Policy?

2. How Is The Reconstruction Of The Green-Space Arrangement (RTH) Policy In Indonesia Based On The Value Of Justice?

\section{METHOD OF RESEARCH}

This study uses a constructivist legal research paradigm approach. The constructivism paradigm in social science is a critique of the positivist paradigm. According to the constructivism paradigm of social reality that is observed by a person cannot be generalized to everyone, as positivists usually do [3].

This research uses descriptive-analytical research. Analytical descriptive research is a type of descriptive research that seeks to describe and seek answers fundamentally about cause and effect by analyzing the factors that cause the occurrence and appearance of a particular phenomenon or event. 
Agus Widodo et al., Sch Int J Law Crime Justice, Mar, 2021; 4(3): 159-165

The method of approach in research using the method (socio-legal approach). The sociological juridical approach (socio-legal approach) is intended to study and examine the reciprocal relationship that is associated in real terms with other social variables [4].

Sources of data used include primary data and secondary data. Primary data is data obtained from field observations and interviews with sources; While Secondary Data is data consisting of:

1. Primary legal materials, namely binding legal materials in the form of prevailing laws and regulations and have something to do with the issues discussed, among other things, in the form of Legislation related to regional policies in poverty alleviation. [5]

2. Secondary legal material, namely legal material whose nature provides an explanation of the primary legal material.

3. Tertiary legal materials are legal materials that provide further information on primary and secondary legal materials.

Research that is associated with the socio-legal approach is research that analyzes problems that are carried out by combining legal materials (which are secondary data) with primary data obtained in the field, supported by prior to secondary legal materials, in the form of writings of experts and existing legal policies.

\section{RESEARCH RESULT AND DISCUSSION 1. Obstacles That Arise In Indonesia's Green-Space Arrangement (RTH) Policy}

Historically Speaking, Long Before current the Law exists, The arrangement of RTH actually already exists and is regulated in the Minister of Home Affairs Instruction Number 14 of 1988 concerning Green Open Space Arrangement in Urban Areas, then it was revoked and replaced by the Regulation of the Minister of Home Affairs Number 1 of 2007 concerning the Arrangement of Green Open Space in Urban Areas.

These efforts have been made colliding with the dynamics of development in Indonesia, and in the city of Semarang especially as well as the existence of several influential internal and external factors so that the spatial plan, in this case, the implementation of green open spaces that has been compiled, is helpless in accommodating these developments. This phenomenon causes the city of Semarang to experience several changes which have resulted in various spatial problems, including; the unmet spatial structure pattern, environmental degradation, and provision of green open space, so that in turn it will affect the region's ability to face global competition in the future.

The various external and internal factors referred to include the expansion of settlements to outer-urban areas, changes in the structure and patterns of spatial use, as well as various other factors that affect the helplessness of the spatial plan that has been compiled. The product of this plan must be maintained through spatial instruments through governance such as space utilization permits, building construction permits, so that the use of space is in accordance with the plan, for example, the green open space in an area must meet $30 \%$ of its area by increasing development with pay attention to environmental conditions. Spatial use control is also an important element of a planning outcome. Green open space includes several things that must exist in the urban area of an area so that it can be a supporting indicator for the development of an urban area.

Several laws and regulations at the central regional level related to green open space in the city of Semarang are listed in Regional Regulation Number 14 of 2011 concerning RTRW for Semarang City 20112031, Regional Regulation Number 12 of 2011 concerning RPJMD 2010-2015. Even though RTH has been included in the RTRW and RPJMD Regional Regulations, the management of RTH carried out by the Semarang City Government has not been optimal. This can be seen based on data in 2013 where the public green open space was only 7.3 percent of the total area of Semarang City. However, along with the increasing seriousness of the City Government, the achievement of the percentage of RTH in Semarang City continues to increase for the sake of the goal of increasing the Green Open Space to $59.05 \%$ by 2021.

To fulfill the area of green open space of $30 \%$, the Semarang City Government will do it for 4 (four) years. The green open space management program, which was included in the tagline "Semarang Setara" then "Semarang Hebat", was originally an inherent policy that could not be separated from the desire of the Semarang City Government in its efforts to attract domestic and foreign tourists to visit Semarang City [6]. The general policy that had intended to increase the Regional Original Revenue (PAD) from the tourism sector was finally refined and at the same time the management of Semarang's green open space was carried out in accordance with the provisions of the legislation, because it was realized that the natural and geographical potential of the City of Semarang was very conducive to realizing all of the goals ideals. For this reason, the Semarang City Government continues to strive to fulfill the area of Green Open Space, both public Green Open Space and private Green Open Space.

The area of public green open space in the city of Semarang in 2013 reached $7.3 \%$ of the total area of the city. This shows that the area of public Green Open Space in Semarang City until 2014 is still far from the 
Agus Widodo et al., Sch Int J Law Crime Justice, Mar, 2021; 4(3): 159-165

target of $20 \%$, which seeks to increase land area. Even so, the Semarang City Government is committed to increasing the area of Green Open Space with the 1 (one) District 1 (one) RTH program which is implemented in 2017. As for the private Green Open Space, the provision of private Green Open Space in Semarang City is still often violated by the Public. This is because private Green Open Space has not become mainstream in the community. In contrast to the public Green Open Space which has become mainstream in the community.

The green open space management program that was carried out from 2010-2025 included park maintenance, garden repair, drafting of DED documents, and park development. Although the budget in 20102015 management has always increased. However, it turns out that the existing budget is quite limited. Even so, there is actually one way that can be done to get around the limited budget, namely by implementing Corporate Social Responsibility (CSR). However, in the management of Green Open Space carried out by the City Government, it is not free from problems. Common problems in the management of green open space include limited funds, inadequate human resources, inconsistent maintenance, the selection of plant types that are not according to the ecological requirements for each location, as well as community participation.

Community participation in management is one of the important factors in order to eliminate, or at least reduce the potential for conflicts of interest in spatial use. The ultimate goal of spatial planning, both RTRW and RTRK and RRTR is for the benefit of all levels of society. In Relation to this, According to Hardjasoemantri, if actions are taken in the interests of the community and if the community is expected to accept and obey these actions, then the community must be given the opportunity to develop and express their opinions. On this occasion, Hardjasoemantri [7] also stated that the weakness of green open space planning policies in urban areas is the weak law enforcement and the low awareness of citizens to participate in creating green open spaces around their area. Hardjasoemantri's statement was confirmed by the source with the following statement:

"Lack of adequate supervision on the part of the City Government on building permits, discipline on the existing RTRW, which is caused by weak coordination between related agencies or institutions, so the potential for miscommunication between agencies or institutions at the level of SKPD".

From the information from the sources above, it can be seen that not only is the enforcement of spatial law enforcement weak, but weak coordination between agencies or institutions at the level of related SKPD has been considered a concrete obstacle in the effort to organize and manage Semarang's green open spaces so far.

\section{Reconstruction of the Green-Space Arrangement (RTH) Policy in Indonesia Based on the Value of Justice}

By Paying attention to article 29 of Law Number 26 of 2007 concerning Spatial Planning, it can be seen that each region must have RTH of at least 30 percent of the total area, of which $20 \%$ is allocated for Public and Private RTH, while $10 \%$ is allocated for RTH city forest city parks as areas shelter

Furthermore, by paying attention to Article 1 paragraph 31 of Law Number 26 of 2007, article on Spatial Planning, in conjunction with Regional Regulation of the City of Semarang Number 07 of 2010 concerning Green Open Space where the definition of Green Open Space (RTH) is an elongated area/ pathway and/ or in groups, which use is more open in nature, a place for plants to grow, whether they grow naturally or are intentionally planted.

By paying attention to the change in the function of space in the city of Semarang, which was originally designated as a Green Open Space (RTH) for agrarian activities to become urban areas characterized by agrarian and sub-urban (secondary extension), and that means that it will be more concentrated for residential areas.

Changes in the spatial function of urban areas have caused the absorption of water to decrease so that water can easily run downstream.

Admittedly, shifts in spatial planning are also sometimes carried out to accommodate the will from outside, especially from the owners of capital, to influence the direction of urban spatial planning policies.

Spatial planning, especially in various cities in Indonesia, is still seen only as a means to meet development growth and tends to be oriented towards efforts to achieve economic growth targets or to meet the inevitable development needs of a certain area.

Such urban planning orientation does not take into account the purpose of spatial planning and use in accordance with its designation. Conceptually, the spatial plan should be conceptualized as a comprehensive integrated plan by analyzing all aspects and factors of urban development and development in an integrated series in the form of policy descriptions and basic steps supplemented with data and space-usage map. 
Agus Widodo et al., Sch Int J Law Crime Justice, Mar, 2021; 4(3): 159-165

The principles of spatial use were then corrected and expanded again in Law Number 26 of 2007 concerning National Spatial Planning which was only passed on April 26, 2007. The new spatial planning principles regulation on the use of protected areas and cultivation areas; (3) quality spatial use is achieved to realize spatial function protection; (4) preventing and overcoming the impact on the environment, and creating a balance between the interests of welfare and security.

The definition of Green Open Space (RTH) as stated in article 1 paragraph 31 UUTR and if it is related to article 29 UUTR to provide RTH 30 percent of the city area will be very difficult to implement and useless for environmental harmony.

The phrase "longitudinal area/ lane and/ or grouping" in the sense of RTH in its implementation will encounter difficulties in providing the land as well as being useless in equitable environmental management.

Provision of green open space that spans 30 percent (without interruption) for large urban areas that are already densely populated is very difficult to implement, because of the narrowing of large vacant lands. For example, the determination of green open space for the city of Semarang only depends on the area of Mijen District. Of course, there will be many difficulties in providing land because of the reduction in green open areas caused by official regional regulations to change land-use change.

Provision of green open space covering an area of 30 percent only for one part of a large city area (BWK) for only one part of the city area (for example Mijen District) causes other parts of the city to be constrained by a balanced and balanced environmental management.

The provisions of article 1, paragraph 31 UUTR, which define RTH as an elongated area/ pathway and/ or group, which use is more open in nature, a place to grow plants, whether they grow naturally or intentionally planted, will easily be read as:

a. A very large and uninterrupted area;

b. Used for plants without being close to buildings;

First, as the author has described above, the definition of "a very wide and unbroken area" when it is linked to article 29 UUTR, where every city/ district has to provide RTH of 30 percent of the total area and is only placed in one part of the city area will encounter difficulties. In its procurement and other parts of the city, it will be constrained by the need for it to be harmonious and balanced to its economical needs management.

In fact, currently, the provision of green open space in several big cities has begun to find it difficult to find a really large area for green open space.

Apart from being constrained by finding a really large area as mentioned above, it is also constrained by the problem of balance and distribution of green open space in each BWK.

The area of Mijen District, for example, which was originally designated as an open space for agricultural activities, has changed its function to an urban area characterized by agrarian and sub-urban (secondary extension) through Regional Regulation No.2 of 1990, and that means it will be more concentrated for residential areas.

Changing the function of green open space into residential and industrial buildings shows that there are difficulties in providing a special space for green open space because they are pressured by the need for space for buildings.

Reconstruction of article 1 paragraph 31 UUTR which defines RTH as "an elongated area/ pathway, and/ or grouping, which is more open in nature, a place to grow plants, both those that grow naturally and those that are intentionally planted"

The definition of green open space in context greatly limits the realization of green open space to the maximum, because the meaning of the word "lengthwise/ pathway, and/ or grouping" is understood as a calculation of the area of land that is horizontally overgrown with clustered plants. If we learn from Singapore, the meaning of green open space can also be interpreted as a vertical side. For example, a tall building with dozens of floors, where each floor is partially planted with green plants, can be said to be kawasa or green open space. This kind of limitation will eventually make Singapore able to reach RTH of $80 \%$ by the end of 2019. The conclusion is that if cities in Indonesia can reach a percentage like Singapore, then the approach to meaningful green open space must also be changed.

It should be revised by simply using the word "areas that are grouped horizontally or vertically, which are more open in nature, where plants grow, both those that grow naturally and those that are intentionally planted"

Green Open Space (RTH) does not need to be a "longitudinal / lane and / or grouped area" which is determined in one part of the city area only, but in every 
Agus Widodo et al., Sch Int J Law Crime Justice, Mar, 2021; 4(3): 159-165

part of the city area there should be green open space For example, in the city of Semarang with Regional Regulation Number 1 to 10 of 2004 has mapped the Semarang City area into ten (10) City Area Divisions (BWKs), and all BWKs must have their own RTH.

In managing the urban forest, Malaysia and Singapore, for example, have given more confidence to the private sector. The government requires that in every issuance of a building permit, there must be an open area for plants. So that the responsibility for providing RTH is not solely the responsibility of the government.

Second, green open space may be close to the surrounding buildings, provided that the function of water absorption and other functions (such as air pollution prevention and $\mathrm{O} 2$ production from the plant) is well maintained so that sustainable development can be achieved in an environmentally sound manner.

Thus, environmentally sound development is a conscious and planning effort in development as well as management of resources wisely in development. According to Yakin [8], environmentally friendly development requires the following conditions:

a. Development is loaded with value, in the sense that it must be oriented towards achieving ecological, social, and economic goals.

b. Such development requires careful planning and supervision at all levels.

c. This development calls for the qualitative growth of each individual and society.

A strict separation between green open space and buildings will find it difficult to achieve 3 (three) pillars of environmental law to be maintained, namely the pillars of the economy, environment, and sociocommunity, where the ideal collaboration between the three creates the concept of Sustainable Development, which is then used as a Development Goal which continues the Millennial Development Goals [9].

Between the interests of economic growth and environmental preservation, it can be realized that there are different points of concern. Most economists tend to argue that efficiency and maximum benefits are the best alternatives, while the social costs or environmental costs (social/ environmental costs) have not been fully taken into account [10]. On the other hand, environmentalists and ecologists argue that ethical and social factors are of primary concern. Therefore, production and economic activities must refer to the aspects of equality and fair distribution within certain generations as well as between generations. Thus, resource management refers to aspects of conservation and preservation of the environment. So, the optimal approach to reconcile the two interests in an integrated approach so that economic interests and environmental preservation can work simultaneously. Therefore, there must be a compromise (trade-off) between the 2 (two) interests. From here the basic idea of the need to develop environmentally sound development or sustainable development.

\section{CONCLUSION}

1. Obstacles that arise in the establishment of a Green Open Space are the aspects of law enforcement approaches that are still formalistic and conventional. Law enforcement that does not use a meaningful perspective, namely laws that are stuck in a deadlock in seeking truth and substantial justice, especially in law enforcement. If law enforcement is still formalism, justice and truth (substantial) that seekers of truth and justice crave will not be realized, because only procedural justice is realized.

2. Reconstruction of Green Open Space (RTH) utilization policies for development based on the value of justice can be realized by not only evaluating the law itself, but also its enforcement, particularly on Law Number 26 of 2007 concerning Spatial Planning, Article 1 point 31 concerning the definition of Green Open Space. Article 1 point 31 states that what is meant by green open space is "a longitudinal area/ pathway and/ or group, the use of which is more open, a place for plants to grow, whether they grow naturally or intentionally planted". This limitation is contextually very limiting the realization of a maximum green open space, because the meaning of the word "stretch/ line and/ or group", is understood as a calculation of the area of land that is horizontally overgrown with clustered plants. By seeing other enforcement in Singapore, for example, the meaning of green open space can also be interpreted as a vertical side. For example, a tall building with dozens of floors, where each floor is partially planted with green plants, can be said to be a green open space. This kind of limitation has managed to make Singapore able to realize its RTH to $80 \%$ by the end of 2019 . the conclusion is that if cities in Indonesia can reach a percentage like Singapore, then the meaningful approach to green open space must also be changed.

\section{REFERENCES}

1. Kodoatie, R. J., \& Sjarief, R. (2010). Tata ruang air. Penerbit Andi.

2. Arum, P. (2019). Analisis Faktor-Faktor yang Mempengaruhi Jumlah Penduduk di Kota Semarang Menggunakan Metode Regresi Data Panel. J Statistika: Jurnal Ilmiah Teori dan Aplikasi Statistika. $12 . \quad 36-41$. 10.36456/jstat.vol12.no2.a2227.

3. Faisal. (2010). Menerobos Positivisme Hukum, Rangkang Education, Yogyakarta. 
Agus Widodo et al., Sch Int J Law Crime Justice, Mar, 2021; 4(3): 159-165

4. Johnny, I. (2005). Teori dan Metodologi Penelitian Hukum Normatif, Bayumedia, Surabaya.

5. Moleong, L. (2002). Metode Penelitian Kualitatif, PT Remaja Rosdakarya, Bandung.

6. Sanjaya, A. (2017). Masukan Masterplan Smart City Kota Semarang "Semarang Hebat".

7. Hardjasoemantri, K. (2007). Perencanaan pembangunan hukum nasional bidang lingkungan hidup. Badan Pembinaan Hukum Nasional, Departemen Hukum dan Hak Asasi Manusia RI.

8. Addinul, Y. (2015). Ekonomi Sumberdaya Alam dan Lingkungan (ESDAL): Teori, Kebijakan, dan
Aplikasi bagi Pembangunan Berkelanjutan, Akademika Presindo, Jakarta, 26.

9. Widodo, W., Budoyo, S., \& Pratama, T. G. W. (2018). The role of law politics on creating good governance and clean governance for a freecorruption Indonesia in 2030. The Social Sciences, 13(8), 1307-1311.

10. Aji, A. B. W., Wiyatno, P., Arifin, R., \& Kamal, U. (2020). Social Justice on Environmental Law Enforcement in Indonesia: The Contemporary and Controversial Cases. The Indonesian Journal of International Clinical Legal Education, 2(1), 57-72. 